\title{
SARAH ALLAN, BURIED IDEAS: LEGENDS OF ABDICATION AND IDEAL GOVERNMENT IN EARLY CHINESE BAMBOO-SLIP MANUSCRIPTS: A REVIEW ARTICLE
}

\author{
Mark Edward Lewis*
}

\begin{abstract}
Buried Ideas is a major contribution to the study of early China, and of ancient civilizations in general. It analyzes four important, recently discovered texts that in some manner deal with the idea that the position of the ruler should be transferred by voluntary abdication from one sage to another. In addition to analyzing in detail the arguments of these texts and their relations to the received tradition, it also provides a useful introductory survey of the current state of the study of Chuscript bamboo-slip texts, facilitates direct confrontation with these texts for anyone who desires to pursue them, demonstrates-in association with her earlier monographs-how newly discovered texts have transformed our understanding of early China, offers insights into the origins and deep structure of the Chinese modeling of history as a dynastic cycle/sequence, and shows how working across generic boundaries both improves our understanding of ancient China, and allows more insightful comparisons with other early civilizations.
\end{abstract}

I will begin with an apology to the editors and readers of Early China and to Sarah Allan. This book ideally would have been reviewed by someone more actively involved in the detailed work of reconstructing and analyzing the numerous bamboo- and wooden-slip manuscripts that have been rediscovered in recent decades. I myself am in this regard an interested outsider, who waits for others to do the dirty work and then avails himself as best he can of the fruits of their labor. I will consequently not be able to provide a detailed analysis and evaluation of this major monograph, but will offer only an appreciation of its riches, and suggest a couple of points in which, I believe, the author has underestimated the importance of her own work.

This book offers a detailed examination of four texts extracted from the three major caches of Chu-script bamboo texts: from Guodian 郭 店 Tomb One, from the approximately 1,200 strips purchased in Hong Kong by the Shanghai Museum, and from the approximately 2,500

* Mark Edward Lewis, 陸威儀, Stanford University; email: meliooo@stanford.edu.

(c) The Society for the Study of Early China and Cambridge University Press 2016 
purchased by Tsinghua University. ${ }^{1}$ Because the last two caches were purchased on the black market, and only presumptively looted from $\mathrm{Chu}$ tombs, the issue of their authenticity has inevitably arisen. Professor Allan devotes several pages to this issue, offering detailed reasons that we can accept the texts as genuine, and also believe that they come from tombs that were close in both time and space to the Guodian materials (see pp. 68-70). In brief, these include the physical condition of the strips (saturated in water and stuck together through long-term immersion, mold growth, and ink that fades when exposed to light), the consistent style of the Chu script (which was not well known before the discovery of these manuscripts), the fact that the Shanghai Museum strips were purchased before the Guodian materials were researched and published (but converge in their orthography and both including a couple of previously unknown texts), the vast preponderance of unknown texts (while forgers tend to prefer the less labor-intensive route of adapting received texts), the fact that many previously undeciphered graphs in other excavated materials have been interpreted on the basis of variants found in these "black-market" manuscripts, and the fact that the handwriting indicates the work of a large number of scribes, all of whom would have necessarily been familiar with Chu script. Finally, study of the texts has revealed a complex web of interrelationships with many early transmitted texts and a diversity of inscribed materials, a web which supports claims to authenticity and which also provides much of the contents of Professor Allan's monograph.

This discussion of the authenticity of the two purchased collections is in Chapter 3, "The Chu-Script Bamboo-Slip Manuscripts." This chapter offers an invaluable introduction for anyone who is interested as to current thinking about these $\mathrm{Chu}$-script texts. It discusses the structure of these relatively short writings, their hypothetical relation to the larger texts of the transmitted tradition, the influence of the materials on which they were written (and the impact of later transfer from bamboo strips to silk scrolls as a means of stabilizing the texts in their longer, received forms), the means used to decipher the graphs, theories of the roles of oral and written transmissions as evidenced in the types of "errors" or "loans" that occur, the nature of the Guodian tomb, and the acquisition and possible origins of the other caches. Finally, it discusses some of the

1. The Guodian materials are all now available in a complete annotated translation: Scott Cook, The Bamboo Texts of Guodian: A Study and Complete Translation (Ithaca: Cornell University East Asian Program, 2012). The published versions and studies of all three caches (although less than half the Tsinghua texts have yet been published), and some individual texts, are listed in Professor Allan's notes and bibliography. 
more widely studied texts found at Guodian, notably the celebrated proto-Laozi, and notes some differences in the general character of the three collections. Thus, whereas the texts from Guodian tend to be more abstracting and "philosophical" (naming only the state of $\mathrm{Lu}$ ), many of the texts from the Shanghai Museum collection feature historical vignettes naming many specific people and places. The Shanghai Museum strips also feature more discussions between Confucius and his disciples, and evince a recurring interest in music, songs, and performance. The Tsinghua University strips, to the extent they are known, are often related to the traditional "classics [jing 經]," most notably including a large number of "documents [shu 書]" (see below), but also materials related to the Changes ( $Y i$ 易) and a “Chronicle [Xi nian 繫年]," which records events from the beginning of the Zhou Dynasty to c. 400 B.C.E. and which includes material found in the Zuo zhuan and some received texts.

The four texts in the monograph are chosen by Professor Allan because, as the subtitle indicates, each of them discusses the early legend that the sage-king Yao 堯 abdicated his throne to Shun 舜, although each text employs the story to make different arguments, and all of them differ from the significance attributed to this legend in the transmitted literature. The first text discussed (Chapter 4) is "The Way of Tang Yao and Yu Shun (Tang Yu zhi dao 唐虞之道)," a philosophic essay from Guodian Tomb One arguing that abdication is the fullest expression of humaneness and rightness, so that the yielding of the throne from the best to the best is always and everywhere the ideal mode of

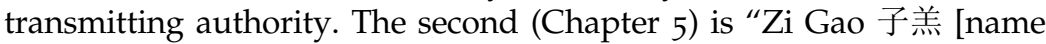
of a disciple of Confucius]," a dialogue between the eponymous disciple and Confucius found among the Shanghai Museum strips which argues that while Shun was made king by Yao because of his outstanding moral character, the progenitors of the ruling lines of the "Three Dynasties [Xia, Shang, and Zhou]" were sired by divine forces and thus literally "Sons of Heaven." At the conclusion of the text Confucius argues that if they had all lived at the same time the three divine offspring would have served the human sage Shun, thus indicating that sagely virtue is more important than even the loftiest birth.

The third text (Chapter 6) is "Rongchengshi 容成氏," a lengthy historico-philosophic chronicle also from the Shanghai Museum collection. This text traces the devolving character of world rulership from an ideal antiquity where power was transferred through abdication; to the time of a certain Youyu Tong 有虞通 who introduced hereditary posts and salaries; to the age of Yao, Shun, and $\mathrm{Yu}$ 禹 when abdication was still employed but the ruler's power depended upon securing the loyalty of the people (the latter being the ideal of transfer in the 
Mencius and the Xunzi); to the shift to hereditary succession at the end of Yu's reign, when his chosen heir was supplanted by his rebellious son. The text concludes with accounts of the virtuous founders of the Shang and the Zhou, the evil conduct of the last rulers of these dynasties (which are not explicitly named), and dramatized depictions of the conditions and behavior which justify rebellion. This text, like "The Way of Tang Yao and Yu Shun," also emphasizes that the ruler's health and the harmony of the world are inseparable, so that abdication is justified by the fact that in old age the rulers' limbs become gnarled, and his senses lose their acuity. The text is also notable for presenting an ideal of cosmic harmony between Heaven and Earth, rather than the mandate of Heaven or any other divine support, as the basis of political authority.

The final text (Chapter 7) is the "Cherished Instruction [Bao Xun 保 訓]," found among the Tsinghua University collection. In its title and form this work is linked to the "documents [shu 書]" of the Canon of Documents (Shu jing 書經) and the Remaining Zhou Documents (Yi Zhou shu 逸周書). Like the documents in the Shu jing, it claims to record a speech by an exemplary king or minister, in this case a charge from the dying Zhou King Wen to his son, the future King $\mathrm{Wu}$. This speech, according to Professor Allan, articulates a model of government in which any would-be monarch must establish himself at the center (zhong 中) of the world, a center which is defined cosmically, ritually, and ethically. The figure Shun, and his receipt of the throne through abdication, figures only as the first historical example of a person who became king through seeking out and ultimately establishing himself at the center.

Each chapter dealing with a single text follows a similar structure. It introduces the text and says something about its historical or intellectual background, in some cases describes the number and physical state of the strips, and then gives a complete translation (or in the case of the lengthy "Rongchengshi" a detailed summary). Finally, it divides the text into its constituent parts with complete translations and the accompanying modern versions of the graphs alternating with shorter or longer discussions of key intellectual points that help understand the text and its relations to writings known from the transmitted tradition or other tomb finds. After a brief concluding section, each chapter presents an epitome of how Professor Allan attained her reading of the text. This includes identifying all posited emendations or phonetic glosses, and includes references to the relevant versions and articles from the Chinese secondary literature (or earlier Western versions) which she adopts or disputes.

The book represents the culmination of at least three linked projects. First, it brings together a series of earlier articles by Professor Allan on 
these four specific texts, only a couple of which were published in major journals. ${ }^{2}$ In bringing the results of these earlier articles together, the monograph has not only allowed Professor Allan the possibility of fleshing out her earlier analyses and more directly comparing the differing arguments in the four texts, but also of revising her own previous positions. Thus in an earlier article she had argued that the "Rongchengshi" advocated abdication, but in the book she suggests that while it attributes routine abdication to an idealized antiquity, it insists that this practice is no longer applicable in the present day, where political power depends upon benefitting the people and winning their support through frugality in government and harmonizing Heaven and Earth. ${ }^{3}$

2. "Not the Lun yu: The Chu Script Bamboo Slip Manuscript, Zi Gao, and the Nature of Early Confucianism," Bulletin of the School of Oriental and African Studies 72.1 (2009), 115-51; “On Shu 書 ('Documents') and the Origin of the Shang shu 尚書 ('Ancient Documents') in Light of Recently Discovered Bamboo Slip Manuscripts," Bulletin of the School of Oriental and African Studies 75.3 (2012), 547-57; "On the Character zhong 中 in Oracle Bone Inscriptions and the Concept of the Center in Ancient China," in Luogesi Shang wenming guoji huiyi lunwenji 羅格斯商文明國際會議論文集 (Collected Papers from the International Conference on Shang Civilization at Rutgers University), ed. K. Y. Chen (Beijing: Xianzhuang, forthcoming); "The Way of Tang Yao and Yu Shun: Appointment by Merit as a Theory of Succession in a Warring States Bamboo Slip Text," in Rethinking Confucianism: Selected Papers from the Third International Conference on Excavated Chinese Manuscripts, Mount Holyoke College, April 2004, ed. Wen Xing, Special Issue of International Research on Bamboo and Silk Documents: Newsletter 5.2 (2006), 22-46; "What Is a Shu?" Research Essay in the Newsletter of the European Society for the Study of Chinese Manuscripts, April 2011, 1-5.

3. She points out the alternative position, that the "Rongchengshi" advocates abdication as the best form of transferring power, is defended in Yuri Pines, "Disputers of Abdication: Zhanguo Egalitarianism and the Sovereign's Power," T'oung Pao 91.4-5 (2005), 236-68; Pines, "Political Mythology and Dynastic Legitimacy in the Rong Cheng shi Manuscript," Bulletin of the School of Oriental and African Studies 73.3 (2009), 1-27; Pines, "Subversion Unearthed: Criticism of Hereditary Succession in the Newly Discovered Manuscripts," Oriens Extremus 45 (2005-6), 169-75.

Professor Allan cites the "Wu du ['Five Vermin' 五蛽]" chapter of the Han Feizi, along with the "Qu qie" chapter of the Zhuangzi, as texts that like the "Rongchengshi" present a devolutionary model from a primitive utopia to a morally inferior present. (The "Quqie ['Rifling Trunks' 胠筮]" also describes the primitive utopia with a list of sage rulers, while the "Wu du" identifies its sequence of early sages with the first stage of decline.) Although she does not note it, the passage that she cites from the Han Feizi (see p. 219) leads directly to the argument that each earlier sage was meeting the problems of his own day, and that those who "went around praising the Way of Yao, Shun, Tang, $\mathrm{Wu}$, and $\mathrm{Yu}$ in the present day would certainly be laughed at by the new sages." Thus the argument that she attributes to the "Rong Cheng shi," where the practices of past sages cannot be applied to the present day, fits with that in the Han Feizi. 
In addition to allowing her to draw together, revise, and synthesize her earlier work on these documents, the monograph, as noted above, also offers a useful summation of the current state of scholarly work on the Chu-script bamboo-slip manuscripts. In her introductory chapters and those devoted to each of the texts, Professor Allan draws together the earlier work of Chinese, Japanese, and Western scholars. Consequently her notes and bibliography would allow any interested scholar to survey the relevant literature, and to directly enter into the debate over every issue from the identification of specific graphs to the intellectual points being argued.

Finally, the book draws together the entire sweep of Professor Allan's highly productive career. The issue of early Chinese thinking about royal abdication formed the topic of her first book, The Heir and the Sage. ${ }^{4}$ However, this work was based entirely on the received literature in which the early practice of abdication by Yao and Shun was replaced by dynastic succession at the death of Yu. In a structural analysis patterned on the work of Levi-Strauss, she argued that the set of stories on this theme constituted an attempt to mythically reconcile the opposed principles of rule by virtue with rule by heredity. Whereas "historically" the latter replaced the former, the received texts placed the bad rulers who justified replacing one dynasty with another with the bad sons who justified Yao and Shun's practice of abdicating to the best man they could find, rather than passing the throne to their own morally deviant sons. The same texts paralleled the percipience of the early sages-in selecting the lowly man who possessed sagely virtues - with the later dynastic founders ability to find a humble person whose sagely brilliance allowed him to become a "founding minister" (Yi Yin 伊尹 working in the kitchen, Tai Gong 太公 working as a butcher or fishing, Fu Yue 傅說 working as a forced laborer; later also less virtuous parallel figures like Boli Xi 百里徙 and even Guan Zhong 管仲).

Thus in the received literature abdication and virtuous rebellion were mythically fused as parallel methods for shifting rule from one lineage to another. In these accounts the abandoned practice of transferring kingship through abdication remained the hidden truth or origin of relying on hereditary rule periodically modified through the violent transfer of "Heaven's Mandate." In this latest book Professor Allan repeatedly draws on the analysis of her first book, as well as many ideas from The Shape of the Turtle and her numerous articles, while

4. Allan, The Heir and the Sage: Dynastic Legend in Early China (San Francisco: Chinese Materials Center, 1981). This book is based on her 1974 dissertation thesis at Berkeley, and she states that a new edition will be published by SUNY Press. 
using the newly discovered texts to recreate something of the intellectual world in which abdication was actually being debated as an alternative to hereditary rule, and the stories of Yao and Shun were invoked to defend a range of diverse positions. Reading her first book and her latest together offers perhaps our clearest understanding of how "archaeological finds are changing how we think about early China." ${ }^{5}$

I have sketched above some of the major uses of this monograph for scholars and students: as an introductory survey to the study of the Chuscript bamboo-slip manuscripts, as a means of moving directly into the detailed issues involved in studying these texts, as an analysis of the range of ideas about royal abdication that existed in Warring States China, and as our best demonstration of how the addition of excavated texts can change our understanding of the received tradition. (I should also note that, as with many studies of excavated texts, it provides new ways of thinking about the emergence of the texts that formed the received tradition.)

In the balance of this brief review I will elaborate two important insights that the text can provide but does not foreground. First, I will show that, contrary to what Professor Allan states, the paradigm of abdication, as opposed to the idea of a dynastic sequence formed by the shifting of Heaven's Mandate, did not disappear in the "Qin and Han dynasties as an idea for an alternative form of succession." (see p. 11) Second, I will show how working across generic lines, as Professor Allan does in combining her four different texts, provides a superior model both for the study of early Chinese thought, and for the comparative study of Chinese thought and that of the ancient Mediterranean world.

Professor Allan begins the first substantive chapter of Buried Ideas with a sketch of the model of the dynastic cycle against which she analyzes the legends of royal abdication:

The ideas of a dynastic cycle and a changing mandate of heaven served as the foundation for all Chinese political theory before the fall of the Qing dynasty in the early twentieth century. According to this view of history,

5. Allan, The Shape of the Turtle: Myth, Art, and Cosmos in Early China (Albany: SUNY, 1991); "Sons of Suns: Myth and Totemism in Early China," Bulletin of the School of Oriental and African Studies 44.2 (1981), 290-326; "The Identities of Taigong Wang in Zhou and Han Literature," Monumenta Serica 30 (1972-73), 57-99. On how the transformative power of excavated texts has become a commonplace, without always being clearly defined, see Charles Sanft, "Dong Zhongshu's Chunqiu Jueyu Reconsidered: On the Legal Interest in Subjective States and the Privilege of Hiding Family Members' Crimes as Developments from Earlier Practice," Early China 33-34 (2010-11), 141 . 
each dynasty was founded by a good man and continued hereditarily until a descendant of the founder was so depraved that heaven transferred the mandate to rule to another good man, who then established a new hereditary dynasty. This new dynasty continued in the same pattern, coming to an end with an evil ruler, who was replaced by another good man. (Buried Ideas, p. 9. The model is also sketched or indicated on pp. 16-17, 79-80, 82, 103, and elsewhere.)

As she then notes, this theory was first voiced in the earliest chapters of the Shang shu, which justified the Zhou rebellion against the Shang with claims that the evil of the last Shang ruler had led Heaven to transfer its mandate to Zhou. This model thus combined claims to rule through virtue and through heredity, but only papered over the paradox that any rebellion could be justified by claiming that the ruler was not virtuous, but at the same time denounced because it marked a usurpation of hereditary right. This contradiction was solved in the realm of myth through the structural parallels of the accounts of abdication and rebellion.

This account of the "dynastic cycle" with its recurring depraved or evil rulers is ultimately based on Arthur Wright's classic article in which he formulated this idea of the "bad last emperor" to explain Tang accounts of Emperor Yang 煬 of the Sui's failure and their own rise. ${ }^{6}$ This article, or at least the phrase "bad last emperor," has been widely cited and even invoked in variants such as "bad last minister." To the best of my knowledge it has not been subjected to systematic critique, but in fact it is completely wrong. In the vast majority of cases in Chinese history, the last emperor of a dynasty was a youth from the imperial line who was established on the throne so that he could enact a ritual of abdication which was explicitly patterned on the accounts of the yielding of the throne from Yao to Shun to Yu. Moreover, although less important for the case at hand, in most cases the last adult ruler of a dynasty was not "evil" or "depraved" but simply weak or idle, or as in the case of the last ruler of the Chen 陳, simply too devoted to literature (even Emperor Yang of the Sui to some degree falls into this last category). While this might mean that they were not good emperors, they were not evil men. However, the issue here is the routine reliance through most of the history of imperial China on the ritual re-enactment of the myth of Yao and Shun, which thus was not "buried" even in the sense of not surviving as an "alternative form of succession."

6. Wright, "Sui Yang-ti: Personality and Stereotype," in The Confucian Persuasion (Stanford: Stanford University Press, 1960), 47-76. 
The classic study of the enduring, active use of the myth of abdication in order to enact the transfer from one dynasty to another is by Miyakawa Hisayuki.7 As he has shown, the active "revival" of the myth, or more accurately its first political enactment, was the usurpation of Wang Mang 王莽 at the end of the Western Han. First identifying himself with the Duke of Zhou 周公 as the regent protector of the young king, Wang Mang steadily amassed ranks and honors until he was in a position to declare that the Han had lost its mandate (among other reasons because difficulties in producing male heirs demonstrated that the de 德 "potency" of the dynasty had been exhausted) and to stage a ritual in which the young Han emperor yielded him the throne on the model of Yao and Shun. Similarly at the end of the Eastern Han, Cao Cao 曹操 seized the young emperor and held him prisoner, while technically serving him as a high official. His son $\mathrm{Pi}$ 丕 then enacted the complete ritual in which the Han emperor sequentially granted a specified series of titles and honors, Pi declined to assume the title of emperor a requisite number of times, and then finally yielded to the demands of his officials in allowing the Han emperor to abdicate to him. Versions of this ritual marked virtually every dynastic transfer until the Mongol Yuan dynasty. ${ }^{8}$

Miyakawa, whose work is centered on the era of the Northern and Southern dynasties, posits that the practice of ritually transferring power through an "abdication" patterned on Yao and Shun was a tool by which the "aristocracy" of the period co-opted military men who needed to cover up the brute realities of their power, and thereby made them dependent upon the intellectual skills offered by the literati

7. Miyakawa Hisayuki 宮川尚志, “Zenjō ni yoru ōchō kakumei no kenkyū 禪讓に よる王朝革命の研究," in Rikuchō shi kenkyū: seiji shakai hen 六朝史研究: 政治社會篇 (Tokyo: Heirakuji, 1956), 73-172. Similar material is covered in a less thorough manner in Ogata Isamu 尾形勇, “Chūgoku kodai ni okeru teii no keishō-sono seitōka no katei to ronri 中國古代における帝位の繼承一その正當化の過程と論理," Shigaku zasshi 史學雜誌 85 (1976), 308-22.

8. Although the Qin 秦 did not transfer power directly to the Han 漢, nor is there any evidence of a staged abdication as practiced by Wang Mang and later founders, it is noteworthy that the "evil" ruler of Qin, the First Emperor 秦始皇, was succeeded by the hapless Second Emperor who was dominated by Zhao Gao 趙高, who ultimately murdered the Second Emperor and replaced him with his nephew Ziying 子與. Ziying then murdered Zhao Gao, but after only forty-six days as king his capital region fell to Liu Bang 劉邦, the later Han founder, who persuaded him to surrender and transfer the capital to Liu Bang. See Sima Qian 司馬遷 et al., Shi ji 史記 (Beijing: Zhonghua, 1959), 6, 275. Thus although there was no full ritual of abdication, and Liu Bang had no right to accept the ruler's position since he was still subject to Xiang Yu 項羽, a de facto ritual of abdication from a newly established young ruler to the founder of the succeeding dynasty did take place. 
elite. However, the practice (as noted above) long preceded the emergence of any "noble" elite, and endured well after their disappearance. Miyakawa notes that the Tang 唐 founder-whom he argues was, for no particular reason, more confident in his relations with the great families-explicitly claimed that he had seized the throne by force, and expressed reservations about the practice of abdication. Nevertheless, he still performed the ritual and when he was later forced to yield the throne to his son, the later Taizong, this (as in a couple of earlier abdications) was articulated in terms of a transfer from the best to the best on the model of Yao and Shun. Thus abdication as a mode of transferring power from one dynasty to another was a constant feature of Chinese empires for their first 1,200 years, and the primary question is why it was abandoned by the last three dynasties. In all likelihood it was related to the problem of heirs' relations to their mothers, and the shifting balance between the families of empresses and those of the imperial agnates. ${ }^{9}$

In fact the enduring insistence on abdication can be explained in part through immediate problems in enacting the model of transferring the Mandate through force (as opposed to mythically justifying it). Thus the Mencius's and the Xunzi's rejection of both forms of transfer (which Professor Allan cites several times), because only Heaven could shift the Mandate, already highlights the problematic nature of distinguishing mere violent rebellion from a legitimate transfer. At the very least, a staged transfer in which the preceding dynasty "voluntarily" yielded to the next marked a clear and public shift that went beyond brute violence.

There were also long-term developments in the imperial system that encouraged emphasis on the role of abdication. As Professor Allan argues (p. 10), the tension between the two modes of non-hereditary transfer-abdication or rebellion-expressed the tension between the ruler as sage or as heir (who then relied on sage ministers), and also that between obligation to a state or community and loyalty to one's family. As Howard Wechsler demonstrated at length in his study of Tang imperial rituals, in every aspect of ritual and ideology the Tang differed from the Han in the increasing emphasis on the public and celestial grounding of imperial power (which he grouped under the formula from the "Li yun" tianxia wei gong 天下為公, which he translates as "the empire is open to all") and the steady downplaying of the centrality of the ruling house and its ancestral cult (tianxia wei jia 天下為家 “the

9. Jennifer Holmgren, "Imperial Marriage in the Native Chinese and Non-Han States, Han to Ming," in Marriage and Inequality in Chinese Society, ed. Rubie S. Watson and Patricia Buckley Ebrey (Berkeley: University of California Press, 1991), 58-96. 
empire belongs to one family"). ${ }^{10}$ Thus whereas the Han had reported the establishment of a new ruler to the ancestral temple, the Tang reported it to Heaven, with no ancestral rites. Moreover, rulers added the epithet "Heavenly" to their titles, as in Taizong's 太宗 declaration of himself as “Heavenly Khan," or Gaozong's 高宗 and Empress Wu's 武后 self-styling as, respectively, "Heavenly Emperor" and "Heavenly Empress." (Wu Zhao's 武晊 use of the name "Patterned on Heaven, ze tian 則天" was part of the same pattern.) In fact, this shift began in the Han dynasty, as marked by the rise of the cult of Heaven as the central state cult, the associated de-centering of the ancestral cult, the transformation of the feng 封 and shan 禪 sacrifices from a secret offering performed by the emperor alone for the benefit of his own person to a public sacrifice involving the entire court, and the abandonment of the formula "the empire belongs to the Liu 劉 clan." ${ }^{11}$ It is not irrelevant that all these developments - the introduction of abdication between dynasties, the establishment of the cult of Heaven, and the first de-centering of the ruling lineage-all took place under Wang Mang. The celestial aspect of the ruler, as opposed to his familial status, was also subsequently reinforced by the rise of institutional Buddhism and Daoism.

In addition to employing ritual abdication to establish themselves and increasing the emphasis on Heaven to highlight their nature as sages rather than kin, the Tang also employed a variety of methods to link themselves with earlier sage rulers and dynasties in a "political lineage" traced back to Yao and Shun. Thus they made sacrifices to a sequence of political ancestors including Yao, Shun, Yu, Tang 湯, Kings Wen 文 and $\mathrm{Wu}$ 武, and the Han founder. Equally significant, they established the descendants of the two immediately preceding dynasties-the Northern Zhou and the Sui-as formally recognized "Descendants of the Two Kings" who participated in political ceremonies. Conversely, their huge tomb mounds (which used natural mountains) were turned into great, public burials where hundreds of satellite tombs posthumously brought the entire court together as a "political family" in an extended ancestral cult. ${ }^{12}$

Although it lay outside the topics dealt with by Wechsler, the Tang reinforced this "political lineage" of sage rulers and dynasties with

10. Howard J. Wechsler, Offerings of Jade and Silk: Ritual and Symbol in the Legitimation of the T'ang Dynasty (New Haven: Yale University Press, 1985). All the aspects of this change are summarized in his conclusion, on pp. 224-35.

11. Mark Edward Lewis, The Early Chinese Empires: Qin and Han (Cambridge, MA: Harvard University Press, 2007), ch. 8, esp. 185-89; Shi ji, 106. 2821, 2823.

12. Wechsler, Offerings of Jade and Silk, ch. 6-7. 
innovations in historiography. First, they sponsored the writing of histories of the dynasties that had ruled between the Han and themselves, or recognized histories already written as official ones. They also began the practice of having a state-sponsored history bureau compile materials that would be composed into a dynastic history by whatever dynasty succeeded the Tang. ${ }^{13}$ This vision of a dynastic sequence or lineage, in which the legitimacy of each dynasty depended on that of its predecessor and in turn guaranteed that of its successor, took its final form in the Song 宋 dynasty as the zheng tong 正統, the "orthodox political lineage" that was held to form the backbone of Chinese history. This model, in turn, minimized the violence of disruption and the reliance on force, while emphasizing precisely the routinized transmission of sagehood that was articulated in the myths and rituals of abdication.

Not only was the transmission of authority between dynasties increasingly depicted as a formal handing over of sagely wisdom and efficacy, but even the hereditary succession from father to son was also depicted as an act of yielding from the best to the best. As noted above, this pattern was articulated in the Tang when Taizong compelled his father to abdicate power with texts recognizing his son's outstanding talents and character. Taizong in turn passed over his own eldest son to establish the future Gaozong as heir. This act, which was opposed by most of the court, was again justified as an act of transmitting the throne to the best of his sons, thus covering the fact of biological paternity with a patina of shared sagehood. ${ }^{14}$ As many emperors had numerous sons and were ultimately free to choose among them, the Tang and subsequent dynasties often presented father-son succession as a form of sage-to-sage transmission. These were also highly politicized acts, in that substantial factions at court tended to form around each potential heir, with their members contending to place their favorite on the throne and then reap the subsequent rewards.

This centrality in imperial Chinese historiography of a political lineage of sage dynasties established through abdication also suggests a modification of Professor Allan's dispute with Yuri Pines over the

13. Denis Twitchett, The Writing of Official History under the T'ang (Cambridge: Cambridge University Press, 1992.

14. Wechsler, Offerings of Jade and Silk, 80-82, 91-93, 100-106. On the rejection of primogeniture under the Qing, with the ruler selecting whichever of his sons was most "virtuous," largely defined by filial piety, see Evelyn S. Rawski, The Last Emperors: A Social History of Qing Imperial Institutions (Berkeley: University of California Press, 1998), 201-9; Rawski, "The Creation of an Emperor in EighteenthCentury China," in Harmony and Counterpoint: Ritual Music in Chinese Context, ed. Bell Yung, Evelyn S. Rawski, and Rubie S. Watson (Stanford: Stanford University Press, 1996), 151-52, 157-61. 
political significance of the ideas articulated in the early texts studied in her book (see pp. 15-17). According to Professor Pines, the history of Chinese political thought is dominated by "monarchism," the belief in the necessity of a single, omnipotent monarch as the basis of political order. This idea emerged in the Warring States, and the central importance of the myths of abdication was to demonstrate that all people agreed on the centrality of the monarch, with the sole dispute being the manner of choosing successors. ${ }^{15}$ Professor Allan objects that what is truly distinctive about Chinese thought is not the insistence on the ideal of a single, divine ruler-which was common throughout the world-but rather the idea of a dynastic cycle. She then repeats her model of the dynastic cycle based on Arthur Wright's model of the depraved last ruler who is overthrown by the virtuous founder of the next dynasty.

However, once one understands that the model of the dynastic cycle/ lineage was largely based on the continued centrality of abdication and the increasing focus on a sagehood passed from dynasty to dynasty through shared rituals or devotion to canonical texts, then the conflict with Professor Pines can be resolved. The idea of "monarchism" adapts (and indeed translates) Liu Zehua's wangquan zhuyi 王權主義. In Professor Liu's writings, the ideal Chinese ruler is defined not simply by being all-powerful, but by his necessarily combining supreme political authority with supreme intellectual (and more broadly cultural) authority. Such a ruler derives his authority from Heaven, embodies the Way, and ultimately pronounces all political truths. ${ }^{16}$ This model of the ruler underlies the idea of an enduring political realm constituted through the transmission of authority from sage to sage, and from sagely dynasty to sagely dynasty. It is precisely this model that is enacted in stories and rituals of abdication. In short, the model of the "dynastic cycle" properly understood incorporates a vision of monarchism, at least in the form that it was articulated by Liu Zehua.

15. Pines, Envisioning Eternal Empire: Chinese Political Thought of the Warring States Period (Honolulu: University of Hawai'i Press, 2009). See also the articles cited in note 3 above. Professor Pines's idea of "monarchism" is adapted from the work of Liu Zehua 劉澤華. See Zhongguo de wangquan zhuyi 中國的王權主義 (Shanghai: Shanghai Renmin, 200o); Wangquan sixiang lun 王權思想論 (Tianjin: Tianjin Renmin, 2006); "Political and Intellectual Authority: The Concept of the "Sage-Monarch" and Its Modern Fate," in Ideology of Power and Power of Ideology in Early China, ed. Yuri Pines, Paul Goldin, and Martin Kern (Leiden: Brill, 2015), 273-300.

16. Liu, Zhongguo de wangquan zhuyi, part 4; Wangquan sixiang lun, ch. 1-3; "Political and Intellectual Authority," 279-93. 
Before proceeding, I would like to briefly discuss the use of the term "sage" in imperial China. From the time of the First Emperor, this word became the standard epithet for the dynasty and its rulers. All dynasties were described as "sagely," and the same epithet applied to the every aspect of the ruler: his speech, actions, will, beneficence, food, and garments. Thus it had rapidly become a cliché or formula. Most modern scholars argue that officials did not actually "believe" that their rulers -who were usually mediocre at best-were actually sages. Some, like Liu Zehua, argue that the officials and writers used the term to "express what they hoped the ruler would be," but that given their dependence on the ruler's power they could not articulate any alternative. In fact, what the officials or writers believed, or what they hoped, was irrelevant. They no more had to believe that the emperor was a sage than subjects of the Roman Empire had to believe that their ruler was a god, or would posthumously become one. ${ }^{17}$ It was the act of sacrifice, or of verbal adoration, that was central, while subjective states were of no importance. Even in Christianity, the idea that subjective belief in specific propositions was important developed only relatively late. ${ }^{18}$ The sagehood of the ruler was the necessary condition that distinguished a true monarch from a simple man of violence (Augustine's leader of a bandit gang); the ruler and his dynasty were sages, or they were frauds. In this way asserting in imperial China that the ruler was not a sage resembled Lucien Febvre's account of stating in sixteenthcentury France that God did not exist. One could make the assertion, but there was no systematic alternative discourse that would allow one to make sense of the world. ${ }^{19}$

The second major point in which Professor Allan does not do full justice to the value of her book is how the choice to select her materials topically - those relating to the theme of abdication-allows her to work across generic boundaries. The four texts that she works with include two types of masters' literature (one an essay and the other a dialogue), one constructed chronicle, and one speech attributed to an ancient

17. S. R. F. Price, Rituals of Power: The Roman Imperial Cult in Asia Minor (Cambridge: Cambridge University Press, 1984); J. E. Lendon, Empire of Honour: The Art of Government in the Roman World (Oxford: Oxford University Press, 1997), 160-72. Thus Seneca, tutor and adviser to the Emperor Nero, could write a comic piece describing how his predecessor Claudius had turned not into a god, but into a pumpkin, without in any way challenging imperial power, or the imperial cult.

18. Wilfred Cantwell Smith, Believing-an Historical Perspective (Oxford: One World, 1977).

19. Febvre, The Problem of Unbelief in the Sixteenth Century: The Religion of Rabelais, $t$. Beatrice Gottlieb (Cambridge, MA: Harvard University Press, 1982). The argument is usefully summarized in the conclusion, $455-64$. 
monarch on the pattern of the "documents." She is careful to establish the differences this entails for each text, and in the cases of the "Zi Gao" and the "Bao Xun" she devotes considerable attention to the role of generic expectations. Unfortunately she does not highlight and contrast how the influence of genre or type shapes the arguments or attitudes in each text. Such an approach would have considerable value, particularly when contrasted with a simple "philosophical" or "history of ideas" methodology.

The "Way of Tang Yao and Yu Shun" is, as she notes, the most systematic and rigorously philosophical essay, and thus the only one that tries to demonstrate that abdication is the ideal mode of transferring power. It does this through a set of abstracting arguments: 1) abdication is the sole mode in which the ruler does not monopolize resources, and thus the one that most benefits the people and honors the worthy, 2) in yielding the throne to a moral exemplar, the sage inspires all people to imitate that exemplar (e.g., to be filial), 3) abdication accords with the inevitability of human aging, in that it leads the physically declining ruler to give up the throne. From such first principles, exemplified with historical cases, the author systematically demonstrates the superiority of abdication as a mode of transfer. As Professor Allan suggests, it is to refute texts like this that the Mencius 孟子 and Xunzi 苗子 argued about the moral impossibility of abdication (which would put the ruler in the place of Heaven) and the Han Feizi 韓非子 argued that supposed cases of yielding the throne were actually forcible seizures of power. These texts would constitute the philosopher's (or "masters") debate over the possibility or value of routine yielding of the throne.

The "Zi Gao" is also a masters' text (or work of philosophy), but it does not argue about abdication from first principles. The basic point of the text seems to be to use cases from ancient history to contrast the values of lofty birth versus lofty merit. Thus it describes in detail the magical insemination of the mother of each lineage founder of the later three dynasties. These are then contrasted with Shun, who was a humble commoner who became good through filial piety and study, and who was raised up through the percipience of Yao. It concludes that if Shun and the divine progenitors had lived at the same time, the latter would have served the former. This is thus an argument that moral or intellectual excellence is superior to lofty birth, and it fits into the general argument offered by Professor Allan that the tales of abdication were linked to the decline of the hereditary power of the old nobility and the rise of men of service appointed to office.

However, Professor Allan also devotes considerable attention to the figure of Confucius, the master in this dialogue, and the immense prestige that he came to enjoy, or at any rate the impact that he had, among 
all philosophers (see pp. 165-67). She suggests that this dialogue might be using the idealized figure of Shun as a proxy for Confucius. Indeed, in her "Afterthoughts" she garbles the account (see p. 326, in contrast with pp. 148 and 163) in suggesting that it is $\mathrm{Zi} \mathrm{Gao} \mathrm{who} \mathrm{argues} \mathrm{that} \mathrm{Shun}$ would rule the three progenitors, and that this disciple thus leads the reader to imagine that the petty rulers of Confucius's day might have served the sage. While the roles of master and disciple are reversed, it is not impossible that the text meant to hint at Confucius's proper claims to power without having him personally assert them. At any rate, such dialogue scenes in masters' literature routinely exalt the person of the master, so this genre would be an ideal method for indirectly calling for Confucius's right to rule. Such veiled arguments do figure in the Analects, where Confucius denies that he is a sage but also identifies himself as the heir of the sage-king Wen, and as such was protected by Heaven. Mencius likewise makes a veiled suggestion of the possibility that he himself might become a world-ruling sage, without actually asserting it. ${ }^{20}$

The "Rongchengshi" is the most generically complex of the texts. It takes the form of a historical chronicle, and Yuri Pines suggests that it should be regarded as the forerunner of the Shi ji 史記. ${ }^{21}$ Professor Allan (p. 182) counters that the historical account is arranged to express a political theory, so that it should be "read as a philosophical work" and treated as an example of masters' literature rather than history. (This would, of course, not completely contradict Professor Pines, to the extent that Confucius, the master par excellence, served as a model for Sima Qian 司馬遷. ${ }^{22}$ ) Although the work clearly indicates certain philosophical ideas, the fact remains that ideas derived from an account of exemplary periods or figures of the past are different from those argued from first principles, or those dramatized in a dialogue where the speakers are also a potential topic.

One clear example of this is essential to Professor Allan's own argument (as noted above), when she decided that this work should not be treated as advocating abdication as a method of transferring power. This is based on her conclusion that the work's devolutionary model of history assigns the practice of yielding the throne to an idealized

20. Lun yu zheng yi 論語正義, annotated by Liu Baonan 劉寶楠 and Liu Gongmian 劉恭冕, in Xin bian zhuzi jicheng 新編諸子集成, vol. I (Taipei: Shijie, 1974), ch. 8, “Shu er," 148 [7:26], 152 [7:34]; ch. 10, "Zi han," 176 [9:5]; Mengzi zheng yi 孟子正義, annotated by Jiao Xun 焦循, in Xin bian zhuzi ji cheng, vol. 1, ch. 5, “Teng Wen Gong shang," 183-84 [2B:3]; ch. 14, "Jin xin xia," 608-10 [7B:38].

21. Pines, Envisioning Eternal Empire, $65 \mathrm{ff}$.

22. Stephen Durrant, The Cloudy Mirror: Tension and Conflict in the Writings of Sima Qian (Albany: SUNY, 1995), ch. 1-2. 
high antiquity that no longer exists. This commitment to a model of irrevocable change—which also figured in the Zhuangzi 莊子, Dao de jing 道德經, and Han Feizi-meant that any argument to first principles or suggestion that one procedure was proper for all times and places (e.g., the argument in the "Way of Tang Yao and Yu Shun") had to be rejected. In short, history as a mode of making arguments can potentially challenge the more rigorous modes of philosophy.

A second characteristic of constructing arguments in the "Rongchengshi" by using history results from the fact that each stage of decline is marked by the sequential introduction of the techniques that characterized proper government in the time of the authors: attracting the loyalty of the people through frugality, appointing good people to offices that entail salaries, structuring the landscape through water control, encouraging agriculture, and offering just decisions in legal plaints. The final sections justify the possibility of rebellion when rulers proved completely resistant to officials' remonstrances or the laments of the people. Each of these developments is identified with an exemplary figure who, apart from the otherwise unknown Youyu Tong, constitute the conventional sequence of sages that appear in the Shang shu and later texts. Fashioning an authoritative past through assembling exemplary figures (both good and bad), rather than through deriving abstract principles, characterizes several other chronicles or histories from the period. ${ }^{23}$ As will be discussed below, the use of

23. The most celebrated and studied is the Zuo zhuan 左轉, which is also generally understood to espouse a devolutionary model. Early in the text the lingering moral impact of earlier sage rulers is still in evidence, but over the course of the history actors demonstrate increasing savagery and moral corruption. There are also speeches in which actors expound more general moral principles, but these too were conventionally regarded as participating in the general moral decline. For the best approaches to reading this text in relation to political philosophy, see Pines, Foundations of Chinese Thought: Intellectual Life in the Chunqiu Period, 722-453 B.C.E. (Honolulu: University of Hawai'i Press, 2002); David Schaberg, A Patterned Past: Form and Thought in Early Chinese Historiography (Cambridge, MA: Harvard University Press, 2002). For a useful sketch of the "stages of moral decline" in the text, and also its use of exemplary figures, see Michael Nylan, The Five "Confucian" Classics (New Haven: Yale University Press, 2001), 275-302.

Although the Gongyang Commentary is more conventionally understood to exemplify moral judgments through the rectification of naming, many of the cases discussed entail presenting exemplary figures, such as those who demonstrate how "expedient assessment (quan 權)" can be properly or improperly used. The commentators do attempt to turn these cases into general principles, but these efforts are generally regarded as failures. See, for example, Hihara Toshikuni 日原利國, Shunjū Kuyōden no kenkyū 春秋公羊傳の研究 (Tokyo: Sōbunsha, 1976); Joachim Gentz, Das Gongyang zhuan: Auslegung und Kanonisierung der Frühlings und Herbstannalen (Chunqiu), Opera 
exemplary figures from a distant past to construct moral arguments characterizes many other civilizations, most notably ancient Rome, which allows for potentially valuable comparative studies of this mode of argument.

The final text, the "Bao xun," is generically identified with the "documents," which are defined as texts that claimed to be contemporaneous records, primarily of the speeches of model kings and ministers (see pp. 266-77). Professor Allan devotes more time to the discussion of this genre and its characteristics than to any of the others. Her central point that is relevant to the reading of the "Bao xun," in contrast with reading the other texts, is that "there is no philosopher or historian who acts as an intermediary." In reading the speech one could imagine directly confronting or meeting one of the ancient sages (see p. 277). Thus the "Bao xun" presents the words of Zhou King Wen to his son, the later King Wu, when the former was approaching death, and too weak to speak.

There are several other ways in which this text differs from the others in the messages that it delivers, or its mode of delivery. First, it explains its own existence. Because King Wen is ill and approaching death, he says that he is too weak to formally intone his admonitions to his heir, so he must give it in writing. This issue of writings that claim to be speech is a characteristic of the genre, and would certainly have affected how it was read.

This account of the text's origin turns it into a deathbed message in which one sage transfers his throne to another (as the two Zhou founders were routinely paired as sages). Thus, although the primary message in the text is the need for the king to seek and find the "center" (see above), it not only cites Shun as a case of one who received an abdication by finding the center, but also dramatizes the possibility of a hereditary succession which was also a transmission from the best to the best. It also overlaps to a degree with "Zi Gao," in that the message of the text is as much about its speaker as about what he says.

Another key point is that as a "historical" account (with the "documents" and "chronicles" being the product of the two historians who mythically stood to either side of the king), it offers not proofs of generally valid principles, but rather an exemplary individual whose words and actions provide a model for imitation. This includes not only King Wen's remarks on the importance of the center, but also the accounts of earlier exemplars, Shun and Shang Jia Wei, whose actions embody the maxims that King Wen articulates. The document also dramatizes through a particular case the general maxims in the "Way of Tang Yao and Yu Shun"

Sinologica 12 (Wiesbaden: Harrassowitz, 2001); Gentz, "Long Live the King! The Ideology of Power between Ritual and Morality in the Gongyang zhuan 公羊傳," in Ideology of Power, 69-117. 
and the "Rongchengshi" on the necessity that a ruler who has become too old and feeble must yield up his throne to his successor.

A final aspect of the "documents" genre is that the language is often archaizing and formalized. The Analects refers to Confucius using a special "refined" or "formal" speech (ya yan 雅言) in reciting the odes or documents, and in performing rituals. While this refers to a method of oral performance, the written language in these texts also tends to be formulaic, highly fixed, and hieratic. It thus is related to the "ritual language" discussed by Martin Kern in his study of the First Emperor's stone inscriptions. These imposed a "sacralized vision of history" that determines what can be remembered, what must be forgotten, and how any account of the past must be formulated. Such an archaic language, which was also adopted as an ideal from the beginning of the Han dynasty, served to separate the state and its educated servants from the masses. ${ }^{24}$

The final point I would like to make is that this communication of political ideas through using chronicles and speeches to create a usable past out of exemplary figures offers a ground for comparing early Chinese thought with other civilizations, most notably the Roman. Thus Carlin Barton's study of Roman honor argues that the Romans are largely ignored in the history of philosophy because they were slow to deduce general principles, preferring instead to reify and dramatize their values through exempla of the heroic or contemptible who were gathered in historical accounts and in poetry. These exempla, which constituted the mos maiorum or "tradition of the ancestors" that underpinned the power of the Roman aristocracy, found expression in proverbs or maxims which were preferred because they could "touch our emotions." Any aspiration to achieve a more united or systematic articulation of these ideals took the form of formulaic repetitions, rather than synthesis or abstraction, and argument largely consisted of variations on certain repeated stories or themes. Philosophy and abstracting argument only developed when people like Cicero, and later Seneca, were forced to withdraw from public participation in order to survive. ${ }^{25}$ Such ideas merit systematic comparison with the

24. Kern, The Stele Inscriptions of Ch'in Shih-huang: Text and Ritual in Early Chinese Imperial Ritual, American Oriental Serica 85 (New Haven: American Oriental Society, 2000), 148-51; Michael Nylan, "Toward an Archaeology of Writing: Text, Ritual, and the Culture of Public Display in the Classical Period (475 B.C.E.-222 C.E.)," in Text and Ritual in Early China (Seattle: University of Washington Press, 2005), 3-49.

25. Barton, Roman Honor: The Fire in the Bones (Berkeley: University of California Press, 2001), 37 n. 21, 41, 44, 48, 58 n. 125, 59, 69-71, 93, 128, 153-54, 182, 213. See also Thomas Habinek, The Politics of Latin Literature (Princeton: Princeton University Press, 1998), 35-39, 46, 53. 
uses of a history constituted by moral exemplars that figure in various early Chinese texts. Moreover, the rise of philosophy as a retreat from political life has echoes, for example, in Sima Qian's accounts of the origins of Warring States and early Han writings.

In summation, Buried Ideas is a major contribution to the study of early China, and of ancient civilizations in general. It analyzes several important texts that have been recently discovered, provides a useful introductory survey of the current state of the study of Chu-script bamboo-slip texts, facilitates direct confrontation with these texts for anyone who cares to pursue them, demonstrates-in association with her earlier monographs-how newly discovered texts have transformed our understanding of early China, with some modifications offers insights into the origins and deep structure of the Chinese modeling of history as a dynastic cycle/sequence, and shows how working across generic boundaries both improves our understanding of ancient China, and allows more insightful comparisons with other early civilizations.

\section{艾蘭《湮没的思想:出土竹简中的禅让传说与理想政制》 評論}

\section{陸威儀}

\section{提要}

《湮没的思想》一书主要对早期中国和古代文明总体研究作出了重要的 贡献。它分析了四种新近发现的重要竹书, 这些文献均以某种方式论 述了统治者应从一个圣人到另一个圣人自愿进行禅让的思想。除了 详细分析这些竹书的论点以及它们与传统论述之间的关系之外，该书还 提供了一个关于楚竹书研究文献现状的有用介绍, 从而为那些面对楚 竹书而寻求这些研究文献的学者提供了便利 。该书还与她许多早期著 作一起论述了新发现的竹书是如何改变了我们对早期中国的认识，提出 了关于王朝历史循环的中国式理论模型的起源与深层结构的深刻见解， 并且展示了跨越不同文体的壁垒不仅有助于我们对古代中国的认知, 而 且也使我们得以与其他早 期文明进行更有洞察力的比较。

Keywords: Sarah Allan, Buried Ideas, abdication, Chu-script, bambooslip texts, dynastic cycle

艾蘭，《淹沒的思想》，禪讓，楚文字，竹書 